\title{
Alcohol use among medicine and law students in Poland
}

\author{
Wiktor Suchy', Agnieszka Gaczkowska', Adam Pawelczyk', Piotr Pukacki', Robert Chudzik² \\ 1 Poznan University of Medical Sciences, Poland \\ ${ }^{2}$ Medical University of Lublin, Poland
}

\begin{abstract}
Introduction. Alcohol, together with drug use such as marijuana, is a major health concern that may influence the life of both doctors and medicine students. It is therefore important to investigate their habits associated with those hazardous behaviors.

Material and methods. A voluntary survey containing 12 questions regarding their drinking habits and marijuana use was sent to law and medicine students from two cities in Poland, Poznan and Lublin. 814 responses were collected and the results were compiled using STATISTICA 10 program.

Results. Mean age of alcohol initiation was revealed to be very similar in all groups at below 16 years of age. Although majority of students drink less than once a week ( $41 \%$ male and $65.7 \%$ female), men were found to use alcohol much more frequently and in higher quantities than female students. Half of future doctors would stop at the lowest stage on a proposed alcohol intoxication scale, while $11.6 \%$ would venture to the highest, third one. Those values for law students were $36.2 \%$ and $26 \%$, respectively. $70 \%$ of men and $52.9 \%$ of women have tried marijuana. Majority of them smoke less than once a month, but almost a quarter of law students and $15 \%$ of medicine students do it at least once a month.

Conclusions. More emphasis should be put on educating future doctors and general public about dangers associated with hazardous drinking and cannabis use. Prevention of such behaviors should be conducted at an age as young as possible.
\end{abstract}

Keywords: drugs, addiction, hazardous drinking, marijuana.

\section{Introduction}

Alcohol is one of the main causes of death in highly developed countries. In Europe, a quarter of deaths among people aged 15-29 years old is linked to alcohol and dangerous behaviors associated with its consumption [1]. Alcohol overuse is commonly associated with pathological population margin. It should be noted that alcohol is dangerous not only among chronic alcohol abusers, but also among casual consumers (binge drinking). Alcohol overuse also favors experimenting with other psychoactive and illegal substances. Medicine students are no exception and their alcohol drinking habits are similar to other people their age. Future doctors with unhealthy habits may be less effective in educating their patients on leading a healthy lifestyle [2]. Alcohol abuse among students may lead to injuries, conflicts, violent behavior, sexual abuse, learning problems and death [3]. Young, active people with above average intelligence tend to have high levels of discipline, which may give them false sense of control over their addictions. This may further weaken their awareness and lead to reckless and dangerous behaviors. Students often don't realize that the level of alcohol intoxication they consider typical for a night out with friends is indicative of alcohol poisoning. This study attempts to evaluate drinking habits of medical students. As future doctors, they should exhibit a high level of knowledge about the influence of alcohol and its chronic and casual abuse, on human 
body. At the same time, doctors are often associated with alcohol abuse.

\section{Material and methods}

A voluntary survey was conducted in March 2015. Anonymous questionnaires were sent out and placed on internet forums for medical and law students in Poznan and Lublin to fulfill. The survey consisted of 12 questions regarding basic information of the participants (sex, age, university etc.) and their experiences associated with alcohol and marijuana use (Table 1). 814 students filled out the questionnaire.

The characteristics of the group are shown in Table 2 .

The results were compared among medicine and law students. The groups were also divided by the city of residence and of course, male and female participants. Alcohol intoxication levels were suggested based on an artificial scale [5] translated and presented in Table 3.

Only stages 2 to 4 were presented as options in the questionnaire.
The results were compiled using STATISTICA 10 program. Group characteristics were created using basic statistics.

\section{Results}

Mean age of alcohol initiation was revealed to be 15.62 years for both men and women. Those from the village started later, at age 15.99, as compared to city residents at 15.38 years. This age for medicine doctors turned out to be 15.55 years compared to 15.38 for law students. No significant differences were revealed between any of those groups. An average student has his/her first contact with alcohol being under 16 years old. That's when they graduate from gymnasium and proceed to high school. The transition, associated with new environment, more freedom and influence from older students may facilitate alcohol initiation at this particular age.

Table 4 represents the frequency of alcohol consumption of students in aforementioned groups.

Table 1. Questions in the form

\begin{tabular}{|c|c|}
\hline Age & \\
\hline Sex & Male/Female \\
\hline Faculty & Medicine/Law \\
\hline Faculty year & $1-6$ \\
\hline Residence & $\begin{array}{l}\text { - city above } 500000 \text { inhabitants } \\
\text { - city between } 100000 \text { and } 500000 \text { inhabitants } \\
\text { - city below } 100000 \text { inhabitants } \\
\text { - village }\end{array}$ \\
\hline University residence & Poznań/Lublin \\
\hline \multicolumn{2}{|l|}{ Age of alcohol initiation } \\
\hline How often do you drink alcohol & $\begin{array}{l}\text { Every day } \\
5-6 \text { times a week } \\
3-4 \text { times a week } \\
1-2 \text { times a week } \\
\text { less than once a week }\end{array}$ \\
\hline $\begin{array}{l}\text { How much alcohol do you consider safe/normal to drink during one } \\
\text { evening? * } \\
\text { one shot of vodka ( } 50 \mathrm{ml} \text { ) equals one beer; one shot of vodka equals one } \\
\text { drink unless you know your favourite drink contains more shots of vodka }\end{array}$ & $\begin{array}{l}1-2 \text { shots } \\
3-4 \text { shots } \\
5-6 \text { shots } \\
7-8 \text { shots } \\
\text { more than } 10 \text { shots }\end{array}$ \\
\hline $\begin{array}{l}\text { What kind of behaviour do you consider indicative of having drunk too } \\
\text { much alcohol * } \\
\text { In short, when do you think you've had enough to drink }\end{array}$ & $\begin{array}{l}\text { Self control impairment, sluggishness, verbosity } \\
\text { Coordination and balance impairment, aggression } \\
\text { Sleepiness, deep self control and balance impairment, mumbling, } \\
\text { unsteady walk }\end{array}$ \\
\hline Have you ever tried marijuana? & Yes/No \\
\hline If yes, how often do you smoke? & $\begin{array}{l}\text { Every day } \\
\text { Few times a week } \\
\text { Once a week } \\
\text { Few times a month } \\
\text { Less than once a month }\end{array}$ \\
\hline
\end{tabular}


Table 2. Clinical characteristics of the study group

\begin{tabular}{|c|c|}
\hline N & 814 \\
\hline $\operatorname{Sex}(M / F)$ & $307 / 507$ \\
\hline Age (years) & $22.5(18-40)$ \\
\hline Faculty (medicine/law) & $398 / 416$ \\
\hline Year & $\begin{array}{l}\text { 1st }-152 \\
\text { 2nd }-181 \\
\text { 3rd }-161 \\
\text { 4th }-126 \\
\text { 5th }-103 \\
6 \text { th }-91\end{array}$ \\
\hline Residence & $\begin{array}{l}\text { City above } 500000 \text { inhabitants - } 304 \\
\text { City between } 100000 \text { and } 500000 \text { inhabitants - } 196 \\
\text { City below } 100000 \text { inhabitants - } 206 \\
\text { Village - } 108\end{array}$ \\
\hline University residence (Poznań/Lublin) & $592 / 222$ \\
\hline Alcohol initiation age & $15.46(6-23)$ \\
\hline Frequency of alcohol consumption & $\begin{array}{l}\text { Less than once a week }-459 \\
1-2 \text { times a week }-247 \\
3-4 \text { times a week }-74 \\
5-6 \text { times a week - } 18 \\
\text { Every day - } 16\end{array}$ \\
\hline $\begin{array}{l}\text { Amount of alcohol considered safe/normal to drink during } \\
\text { one evening (measured in shots of vodka or equivalent) }\end{array}$ & $\begin{array}{l}\text { Between } 1 \text { and } 2-182 \\
\text { Between } 3 \text { and } 4-287 \\
\text { Between } 5 \text { and } 6-206 \\
\text { Between } 7 \text { and } 8-90 \\
\text { More than } 10-49\end{array}$ \\
\hline $\begin{array}{l}\text { Behavior considered indicative of having drunk too much } \\
\text { alcohol }\end{array}$ & $\begin{array}{l}\text { Self control impairment, sluggishness, verbosity - } 353 \\
\text { Coordination and balance impairment, aggression - } 307 \\
\text { Sleepiness, deep self control and balance impairment, mumbling, unsteady walk - } 154\end{array}$ \\
\hline Past or current marijuana use (yes $/ \mathrm{no}$ ) & $483 / 331$ \\
\hline Frequency of marijuana use & $\begin{array}{l}\text { Every day - } 11 \\
\text { Few times a week - } 25 \\
\text { Once a week - } 12 \\
\text { Few times a month }-41 \\
\text { Less than once a month - } 337\end{array}$ \\
\hline
\end{tabular}

Table 3. Stages of alcohol intoxication based on [5]

\begin{tabular}{ll}
\hline \multicolumn{1}{c}{ Blood alcohol concentration } & \multicolumn{1}{c}{ Exhibited behavior } \\
\hline Stage 1. $0.3-0.4$ permille & Reduction of self-criticism; high mood and self-confidence. Longer reaction time and worsened coordination \\
\hline Stage 2. $0.5-0.6$ permille & Self control impairment, sluggishness, verbosity \\
\hline Stage 3. $0.7-2.0$ permille & $\begin{array}{l}\text { Further coordination and balance impairment, aggression; lower concentration and balance; blood pressure } \\
\text { and heart rate elevated }\end{array}$ \\
\hline Stage 4. $2.0-3.0$ permille & Sleepiness, deep self control and balance impairment, mumbling, unsteady walk \\
\hline Stage 5. $3.0-4.0$ permille & $\begin{array}{l}\text { Deep consciousness impairment leading to coma; reflexes and all senses impaired; lowered blood pressure and } \\
\text { body temperature; possible cardiac arrhythmia and breathing depression }\end{array}$ \\
\hline Stage 6. over 4.0 permille & Coma, cardiac arrhythmia, breathing depression, blood pressure lowering \\
\hline
\end{tabular}

Subtle differences are evident in this particular aspect. About three times more men than women drink 3-4 times a week as well as residents of cities compared to those from villages. The distinction is even more noticeable in regard to drinking every day. Majority of students from both sexes drink less than once a week. Faculty chosen by students has less influence on their drinking habits than sex or original residence where those from the city are likely to drink more often than those from the village.

Table 5 shows how the amount of alcohol considered safe/normal to drink during one evening differs between the groups investigated.

Data show that sex related frequency of drinking corresponds with the amount of alcohol likely to be consumed by both sexes. Female students generally tend 
Table 4. Frequency of alcohol consumption

\begin{tabular}{|c|c|}
\hline Men & $\begin{array}{l}\text { Less than once a week - } 41.0 \% \\
1-2 \text { times a week - } 36.5 \% \\
3-4 \text { times a week - } 15.6 \% \\
5-6 \text { times a week - } 3.3 \% \\
\text { Every day - 3.6\% }\end{array}$ \\
\hline Women & $\begin{array}{l}\text { Less than once a week }-65.7 \% \\
1-2 \text { times a week }-26.6 \% \\
3-4 \text { times a week }-5.1 \% \\
5-6 \text { times a week }-1.6 \% \\
\text { Every day - } 1 \%\end{array}$ \\
\hline Village & $\begin{array}{l}\text { Less than once a week }-72.2 \% \\
1-2 \text { times a week }-19.4 \% \\
3-4 \text { times a week }-3.7 \% \\
5-6 \text { times a week }-3.7 \% \\
\text { Every day - } 0.9 \%\end{array}$ \\
\hline City & $\begin{array}{l}\text { Less than once a week - } 54.0 \% \\
1-2 \text { times a week - 32.0\% } \\
3-4 \text { times a week - } 9.9 \% \\
5-6 \text { times a week - } 2.0 \% \\
\text { Every day - } 2.1 \%\end{array}$ \\
\hline Medicine & $\begin{array}{l}\text { Less than once a week }-58.3 \% \\
1-2 \text { times a week }-29.4 \% \\
3-4 \text { times a week }-7.5 \% \\
5-6 \text { times a week - } 2.5 \% \\
\text { Every day - } 2.3 \%\end{array}$ \\
\hline Law & $\begin{array}{l}\text { Less than once a week }-54.6 \% \\
1-2 \text { times a week }-31.2 \% \\
3-4 \text { times a week }-10.6 \% \\
5-6 \text { times a week }-1.9 \% \\
\text { Every day - } 1.7 \%\end{array}$ \\
\hline
\end{tabular}

to drink less than male students. Students from villages are however more likely to go to the extremes as twice as many of them would drink more than 10 shots of vodka than those from the city. As before, there is no major distinction between medicine and law students. However, medicine students are more likely to stop at 1 or 2 shots (27.1\%) than law students (17.8\%).

Table 6 shows what behavior is considered by students from the investigated groups as being indicative of having drunk too much alcohol.

This variable finally differentiates medicine and law students. $26 \%$ of the latter group would stop at stage 4 of alcohol intoxication scale, the highest presented in the questionnaire. Roughly one in ten medicine students would venture that far, with half of them stopping at stage 2 (lowest presented to choose from). Only $36.2 \%$ of law students would finish drinking that early. Half of women in the study would bring drinking to a halt at the lowest stage while only $30.6 \%$ men would stop that early. Almost twice as many male students $(27 \%)$ are likely to drink up until stage 4 symptoms occur; only $14 \%$ of women would drink as far as that.
Table 5. Amount of alcohol considered safe/normal to drink during one evening (measured in shots of vodka or equivalent)

\begin{tabular}{|c|c|}
\hline Men & $\begin{array}{l}\text { Between } 1 \text { and } 2-16.9 \% \\
\text { Between } 3 \text { and } 4-29.6 \% \\
\text { Between } 5 \text { and } 6-25.7 \% \\
\text { Between } 7 \text { and } 8-16.3 \% \\
\text { More than } 10-11.4 \%\end{array}$ \\
\hline Women & $\begin{array}{l}\text { Between } 1 \text { and } 2-25.6 \% \\
\text { Between } 3 \text { and } 4-38.7 \% \\
\text { Between } 5 \text { and } 6-25.0 \% \\
\text { Between } 7 \text { and } 8-7.9 \% \\
\text { More than } 10-2.8 \%\end{array}$ \\
\hline Village & $\begin{array}{l}\text { Between } 1 \text { and } 2-25.0 \% \\
\text { Between } 3 \text { and } 4-30.6 \% \\
\text { Between } 5 \text { and } 6-25.0 \% \\
\text { Between } 7 \text { and } 8-10.2 \% \\
\text { More than } 10-9.3 \%\end{array}$ \\
\hline City & $\begin{array}{l}\text { Between } 1 \text { and } 2-22.0 \% \\
\text { Between } 3 \text { and } 4-36.0 \% \\
\text { Between } 5 \text { and } 6-25.5 \% \\
\text { Between } 7 \text { and } 8-11.2 \% \\
\text { More than } 10-5.5 \% \%\end{array}$ \\
\hline Medicine & $\begin{array}{l}\text { Between } 1 \text { and } 2-27.1 \% \\
\text { Between } 3 \text { and } 4-37.2 \% \\
\text { Between } 5 \text { and } 6-20.9 \% \\
\text { Between } 7 \text { and } 8-9.0 \% \\
\text { More than } 10-5.8 \%\end{array}$ \\
\hline Law & $\begin{array}{l}\text { Between } 1 \text { and } 2-17.8 \% \\
\text { Between } 3 \text { and } 4-33.4 \% \\
\text { Between } 5 \text { and } 6-29.6 \% \\
\text { Between } 7 \text { and } 8-13.0 \% \\
\text { More than } 10-6.2 \%\end{array}$ \\
\hline
\end{tabular}

Table 7 reveals what percentage of students evaluated in the study have ever tried marijuana.

There is almost no difference between faculties and only slight one between sexes and different residencies. Only $52.9 \%$ of women have ever tried marijuana whereas $70 \%$ of men have ever had any association with the drug. As for the students from cities and villages those values are $61.5 \%$ and $45.4 \%$, respectively. Additional distribution of the answers between male and female students from both faculties who admitted to smoking cannabis was made (Table 8) showing the frequency of their marijuana use. Most of those who ever tried marijuana do not do it regularly but a relatively high percentage (between 10\% and 37\% depending on sex and faculty) do it at least few times a month, male law students being the most frequent smokers.

It should be noted, however, that this representation might not be accurate as the group of smokers within the study was low to begin with. Dividing it by frequency of use further dilutes the number of individuals amounting for each \% point. 
Table 6. Behavior considered indicative of having drunk too much alcohol

\begin{tabular}{cl}
\hline Men & $\begin{array}{l}\text { Self control impairment, sluggishness, verbosity - 30.6\% } \\
\text { Coordination and balance impairment, aggression - 42.3\% } \\
\text { Sleepiness, deep self control and balance impairment, mumbling, unsteady walk - 27.0\% }\end{array}$ \\
\hline \multirow{2}{*}{ Women } & $\begin{array}{l}\text { Self control impairment, sluggishness, verbosity - } 51.1 \% \\
\text { Coordination and balance impairment, aggression - 34.9\% } \\
\text { Sleepiness, deep self control and balance impairment, mumbling, unsteady walk - 14.0\% }\end{array}$ \\
\hline \multirow{2}{*}{ Village } & $\begin{array}{l}\text { Self control impairment, sluggishness, verbosity - 44.4\% } \\
\text { Coordination and balance impairment, aggression - 34.3\% } \\
\text { Sleepiness, deep self control and balance impairment, mumbling, unsteady walk - 21.3\% }\end{array}$ \\
\hline \multirow{2}{*}{ City } & $\begin{array}{l}\text { Self control impairment, sluggishness, verbosity - 43.2\% } \\
\text { Coordination and balance impairment, aggression - 38.2\% } \\
\text { Sleepiness, deep self control and balance impairment, mumbling, unsteady walk - 18.6\% }\end{array}$ \\
\hline \multirow{2}{*}{ Medicine } & $\begin{array}{l}\text { Self control impairment, sluggishness, verbosity - 50.8\% } \\
\text { Coordination and balance impairment, aggression - 37.7\% } \\
\text { Sleepiness, deep self control and balance impairment, mumbling, unsteady walk - 11.6\% }\end{array}$ \\
\hline \multirow{2}{*}{ Law } & $\begin{array}{l}\text { Self control impairment, sluggishness, verbosity - 36.2\% } \\
\text { Coordination and balance impairment, aggression - 37.7\% } \\
\text { Sleepiness, deep self control and balance impairment, mumbling, unsteady walk - 26.0\% }\end{array}$ \\
\hline
\end{tabular}

Table 7. Past or current marijuana use

\begin{tabular}{|c|c|c|}
\hline Men & \multicolumn{2}{|c|}{$\begin{array}{l}\text { Yes }-70.0 \% \\
\text { No }-30.0 \%\end{array}$} \\
\hline Women & \multicolumn{2}{|c|}{$\begin{array}{l}\text { Yes }-52.9 \% \\
\text { No }-47.1 \%\end{array}$} \\
\hline Village & \multicolumn{2}{|c|}{$\begin{array}{l}\text { Yes }-45.4 \% \\
\text { No }-54.6 \%\end{array}$} \\
\hline City & \multicolumn{2}{|c|}{$\begin{array}{l}\text { Yes }-61.5 \% \\
\text { No }-38.5 \%\end{array}$} \\
\hline \multirow{2}{*}{ Medicine } & Male students & $\begin{array}{l}\text { Yes }-69.3 \% \\
\text { No }-30.7 \%\end{array}$ \\
\hline & Female students & $\begin{array}{l}\text { Yes }-55.2 \% \\
\text { No }-44.8 \%\end{array}$ \\
\hline \multirow{2}{*}{ Law } & Male students & $\begin{array}{l}\text { Yes }-70.7 \% \\
\text { No }-29.3 \%\end{array}$ \\
\hline & Female students & $\begin{array}{l}\text { Yes }-50.6 \% \\
\text { No }-49.4 \%\end{array}$ \\
\hline
\end{tabular}

Table 8. Frequency of marijuana use among male and female students

\begin{tabular}{lccccccc}
\hline & & Every day & Few times a week & Once a week & Few times a month & Less than once a month \\
\hline \multirow{2}{*}{ Medicine } & Male & $1.0 \%$ & $8.0 \%$ & $3.0 \%$ & $8.0 \%$ & $80.0 \%$ \\
\cline { 2 - 7 } & Female & $2.3 \%$ & $1.5 \%$ & $0 \%$ & $6.2 \%$ & $90.0 \%$ \\
\hline \multirow{2}{*}{ Law } & Male & $4.6 \%$ & $10.2 \%$ & $7.4 \%$ & $14.8 \%$ & $63.0 \%$ \\
\cline { 2 - 7 } & Female & $1.6 \%$ & $3.1 \%$ & $0.8 \%$ & $7.0 \%$ & $87.5 \%$ \\
\hline
\end{tabular}

\section{Discussion}

Mean age of alcohol initiation is very similar among students from all investigated groups. Therefore sex, residence and future faculty do not have any influence on further differences in alcohol drinking behavior (frequency and volume of liquor consumption and their manners after "hitting the bottle"). As young age of alcohol initiation is a risk factor for future binge drinking [6] it should be noted that individuals from all groups are equally susceptible to this major health concern.

More male than female physicians report hazardous (large amounts and/or frequent) drinking [7] and the study clearly shows that this tendency starts at least as early as during medical studies. However, there is a higher percentage of female doctors presenting hazardous drinking than women in general population. A lower percentage of hazardous drinkers is exhibited among male doctors than men in general population 
[7]. The same concurrence is exhibited in regard to marijuana use among female and male doctors (higher in the latter group) as well as female and male students (Table 8). Additionally, higher illegal drug use is reported among doctors than in general population [7] which is concerning, as the group meant to educate and set an example for others is using more than those they should supervise and educate.

As apparent as the tendency among all students to drink excessively is from this study, it is not as observable in real life. One of the reasons may be the fact that students with drinking problems are more likely to seek help in their peers and parents [8] than any institutions able to reliably measure the magnitude of the problem. Drinking problems among students remain therefore not only mostly unsolved but, more importantly, unidentified.

The fact that medicine students are more likely to recognize too high alcohol intoxication (Table 6) than their peers from law school may be comforting, but the percentage of alcohol over-users among physicians suggests that this knowledge does not help them reduce the magnitude of the problem in their own behavior.

Preventive measures should be taken at an age as young as possible as cannabis users are more prone to failing their studies [9]. Additionally, marijuana use is known to have a negative influence not only on physical but mental health [5] which may in turn lead to lower competence of doctors exposed to drugs, not to mention legal problems that may significantly harm their career.

\section{Conclusions}

More emphasis should be put on educating both medical students and general public about dangers associated with hazardous drinking and drug use. As doctors are often the first to respond to their patients exhibiting signs of substance over-use, they should be competent enough not only to help others but also control and avoid being exposed to the problem themselves. It is especially important regarding the fact that quarter of deaths in young people is related to alcohol use.

\section{Acknowledgements}

\section{Conflict of interest statement}

The authors declare that there is no conflict of interest in the authorship or publication of contribution.

\section{Funding sources}

There are no sources of funding to declare.

\section{References}

1. Zadarko-Domaradzka M, Zadarko E, Barabasz Z, Sobolewski M. Alcohol use and health-risk behaviours among academic students in Podkarpackie. Przegl Lek. 2013;70(8):546-50.

2. Frank E, Rothenberg R, Lewis C, Belodoff BF. Correlates of physicians prevention-related practices. Findings from the Women Physicians. Health Study. Arch Fam Med. 2000;9:359-367.

3. Ham LS, Hope DA. College students and problematic drinking: A review of the literature. Clin Psychol Rev. 2003;23:719-759.

4. Anderson P. Global use of alcohol, drugs and tobacco. Drug Alcohol Rev. 2006;25(6):489-502.

5. Klimkiewicz A. Ostre zatrucie alkoholem. http://gastrologia.mp.pl/zatrucia/show.html?id=81259 (accessed 15.05.2015).

6. Elisaus $P$, Williams $G$, Bourke $M$, Clough $G$, Harrison A, Verma A. Factors associated with the prevalence of adolescent binge drinking in the urban areas of Greater Manchester. Eur J Public Health. 2015 Oct 1. pii: ckv115. [Epub ahead of print].

7. Voigt K, Twork S, Mittag D, Göbel A, Voigt R, Klewer J, Kugler J, Bornstein SR, Bergmann A. Consumption of alcohol, cigarettes and illegal substances among physicians and medical students in Brandenburg and Saxony (Germany). BMC Health Serv Res. 2009 Dec 3;9:219.

8. Oster-Aaland L, Lewis MA, Neighbors C, Vangsness J, Larimer ME. Alcohol poisoning among college students turning 21: do they recognize the symptoms and how do they help? J Stud Alcohol Drugs Suppl. 2009 Jul;(16): 122-30.

9. Gignon M, Havet E, Ammirati C, Traullé S, Manaouil C, Balcaen T, Loas G, Dubois G, Ganry O. Alcohol, cigarette, and illegal substance consumption among medical students: a cross-sectional survey. Workplace Health Saf. 2015 Feb;63(2):54-63.

Acceptance for editing: 2015-02-10 Acceptance for publication: 2015-03-30 